\title{
Financial risk-processing in a regional bank
}

\author{
Svetlana Vyatcheslavovna Zenchenko \\ The North Caucasus Federal University. \\ Institute of Economics and Management \\ Chair of Finance and Credit \\ Stavropol, Russia \\ zen_sveta@mail.ru
}

\author{
Inessa Vyatcheslavovna Penkova \\ The North Caucasus Federal University. \\ Institute of Economics and Management \\ Chair of Business Informatics \\ Stavropol, Russia \\ panacea_inessa@mail.ru
}

\author{
Alexey Gennadyevich Zaytsev \\ Orel State University named after I.S. Turgenev \\ Institute of Economics and Management \\ Chair of Marketing \\ Orel, Russia \\ cbap@bk.ru
}

\begin{abstract}
The article observes the basic theoretical background of forming the "financial risk-processing" concept. Authors give its definition and identify the key areas of the financial risk-processing practical application to the regional banking system. It is settled the correlation between the riskprocessing and the strategic development policy of the credit organization in the face of uncertainty. In order to activate and improve the effectiveness, the risk-management algorithm is proposed. It finds out the coherent plan of measures and actions to optimize the reserve accumulation process. The plan is designed based on "from AS IS to TO BE» model as part of the implementation of the financial risk-processing in regional bank.
\end{abstract}

Keywords- financial risk-processing, development strategy, uncertainty, bank, risk-management, model "from AS IS to TO $B E^{\prime \prime}$

\section{INTRODUCTION}

Nowadays many financial transactions are carried out in conditions of uncertainty. This causes the need to monitor unsafe events and manage the consequences of possible threats, which is based on risk-processing. The effective functioning of any financial and credit organization, including banks, depends on the quality and efficiency of information systems, technological models applied to identifying risks.

Typically, the understanding the necessity of risk processing associated with other elements range of business activity, appears only in the implementation of major general banking projects requiring comprehensive analysis of both environmental factors and internal environment. Often goalsettings of resembling projects are aimed at the diversification of services provided, or increasing internal transparency, degree of manageability and controllability of financial organization at its different levels. In this case, the risk management is not separate from the key source of the suppositional improvements and it is involved as an essential direction and strategic development policy element of the bank, the design of which includes, on the one hand, the characteristics of the organization itself, and on the other, regional or more global progress trends.

The relevance of the study concerning various aspects of risk-processing is proved by the escalating scientific and practical interest in this area. This is reflected in the diverse publications of domestic and foreign authors. So, S.Avdoshin and E.Pesotskaya explore the problems of applying different information technologies in the financial risk management [1]. G.Avagyan and M.Saitova analyse the characteristics of regional banking cluster [2]. E.Altuhova, V.Zotov, M.Markov develop a methodical approach to risk management in the regional commercial bank [3]. S.Vayn investigates trends and resource to optimize a modern bank [4]. V.Shumilova, A.Karataev offer information model assessment of financial risks in different industries [5]. Among foreign scientists it is worth mentioning such authors as: J. Bessis with a study of risk management in the banking sphere [6], O. Kosta, J. Hahn and S. Levi who analyse emerging markets including the financial banking sector [7], A. Meyer, J. Armstrong and M.Zelmer who overviewed the risk management tools in Canadian banks [8].

Despite widespread scientific debate on risk management in various financial institutions, it remains poorly studied the innovative direction such as financial risk processing in the regional banking system and its correlation with strategic planning at the meso- and micro- levels. So, this direction states the research keynote within the paper submitted.

\section{MAterials AND MethodS (MODEL)}

The stated purpose required to solve specific problems:

to formulate the definition of the "financial riskprocessing" concept basing on identifying the theoretical and practical prerequisites for its emergence and penetration into the practice of organizations' economic activity; 
to identify the interrelation of the financial risk-processing and Bank Strategic Policy;

to develop an algorithm and a consistent plan of measures and actions to optimize the process of reserve accumulation based on the implementing financial risk-processing into the organization's activities in order to activate and improve the effectiveness of risk management and the bank strategic policy.

The methodology for achieving the goal, solving problems and obtaining results is based on applying system analysis approaches and using the model "from AS IS to TO BE".

\section{RESULTS AND DISCUSSION}

To investigate the specifics of the financial risk-processing in the regional banking sector application we should start with analysing the theoretical and practical background of this innovative phenomenon and term. Such examination will give the possibility to determine the terms and terminology used, which in future will enable us to select and introduce the tools and models that are adequate to our tasks.

\section{A. Backgrounds to define the term "financial risk-processing"}

Risk management is one of the key areas of management in the banking field. The main task of risk management is to provide relevant formalized information on the expecting occurrence and the consequences of risk events, to identify and select ways and means to overcome threats, to control reactions and to detect external and internal feedback. As it is known, the process of identifying hazards is also actualized by the fact that the CBR (the Bank of Russia) withdraws licenses from banks with unsatisfactory financial condition that conduct equivocal, opaque and unbalanced operations. That is, such banks include those whose activities demonstrate a variety of unmanageable or poorly managed risks, namely: liquidity and low solvency risk, legal, reputation, operational and others. At the same time, as it can be seen from the data in Table 1, banks in different Federal Districts are exposed to varying degrees of risks, which leads to a reduction in their number in the regions. The most efficient risks overcomers are the credit and financial organizations of the South and NorthWest, where licenses have been withdrawn in less than $12 \%$ in three years. In the 2012-2015 period, the North Caucasus Federal District demonstrated the most complicated conditions when $53.6 \%$ of banks have lost their licenses [1].

The choice of risk response tools depends on the risk type: functional (internal), external and financial. According to this typology, financial risks can be classified by subspecies [9].

1. Interest rate risk is associated with losses in the value of interest-bearing portfolio when interest rates change.

2. Credit risk arises from the failure to meet loan commitments and the unsustainable provisioning process.

3. Liquidity risk appears when there is insufficient funds to repay the bank's obligations.

4. Price risk is associated with losses due to changes in quotations for portfolio instruments.
5. Currency risk may cause losses due to fluctuations in the exchange rate during sales transactions.

6. Market risk is based on opportunistic changes in financial markets.

7. Investment risk is related to the activity of the bank's capital investments.

TABLE I. FUNCTIONING CREDIT ORGANIZATIONS FOR THE FEDERAL DISTRICTS OF RUSSIA (2012-2015) ${ }^{\mathrm{a}}$

\begin{tabular}{|l|c|c|c|c|c|}
\hline Federal District (FD) & $\mathbf{0 1 . 0 1 . 1 2}$ & $\mathbf{0 1 . 0 1 . 1 3}$ & $\mathbf{0 1 . 0 1 . 1 4}$ & $\mathbf{0 1 . 0 1 . 1 5}$ & $\mathbf{0 1 . 0 7 . 1 5}$ \\
\hline Total RF & $\mathbf{9 7 8}$ & $\mathbf{9 5 6}$ & $\mathbf{9 2 3}$ & $\mathbf{8 3 4}$ & $\mathbf{7 9 7}$ \\
\hline Central FD & 572 & 564 & 547 & 504 & $\mathbf{4 7 9}$ \\
\hline Including Moscow & $\mathbf{5 0 2}$ & $\mathbf{4 9 4}$ & $\mathbf{4 8 9}$ & $\mathbf{4 5 0}$ & $\mathbf{4 2 3}$ \\
\hline North-Western FD & 69 & 70 & 70 & 64 & 61 \\
\hline Southern FD & 45 & 46 & 46 & 43 & 43 \\
\hline North-Caucasus FD & 56 & 50 & 43 & 28 & 26 \\
\hline Volga FD & 111 & 106 & 102 & 92 & 91 \\
\hline Ural FD & 45 & 44 & 42 & 35 & 32 \\
\hline Siberian FD & 54 & 53 & 51 & 44 & 41 \\
\hline Far Eastern FD & 26 & 23 & 22 & 22 & 21 \\
\hline Crimean FD & - & - & - & 2 & 3 \\
\hline Regional Banks & $\mathbf{4 7 6}$ & $\mathbf{4 6 2}$ & $\mathbf{4 3 4}$ & $\mathbf{3 8 4}$ & $\mathbf{3 7 4}$ \\
\hline
\end{tabular}

The variety and complexity of financial risks involves the working out a wide range of tools for their identification, definition, detailing, optimizing quickness and methods of feedback. Thereafter there is a need to introduce an appropriate business process to create and form easily applicable universal methods for identifying threats and overcoming their consequences. Such a process we will call "financial riskprocessing". We note that multipurpose financial riskprocessing is comprehensively ensured and depends directly on the means and methods of its digitization, namely: the software and automation tools used, algorithms and forms to communicate and disseminate information both inside and outside the bank.

\section{B. Risk-processing and bank strategic policy correlation}

Forming an effective strategic policy for regional bank under uncertainty is based on the analysing and processing risks and possible threats. Based on the "Risk Management Policy of the Bank of Russia" (dated March 23, 2016) [9], we should note that the risk management is aimed at setting up the formation and implementation of measures that contribute to the more efficient organization functions under uncertainty. At the same time, the financial losses reduction may not be prior, taking into account the social significance and wide range of the bank's activities. In the case of regional banks, the financial loss risk is at the heart of strategic planning, and it is advisable to analyse possible threats and dangers using financial risk-processing based on key risk management principles:

- responsibility and authority implies compliance with the obligations to implement risk-processing according the competence of corresponding employees; 
- the priority of the functioning objectives and the mission distributes the benefits between the goal and the means to achieve it, i.e. to prevent possible financial losses should not prevail over the measures resolve tasks within the mission;

- improving activities implies a prolonged functional efficiency increase in the organization with the introducing innovative business processes, including the risk management optimization;

- integration into business processes is aimed at introducing risk-processing into various types of bank economic activities in order to reduce the impact of internal and external threats;

- awareness means conducting a preliminary identification and analytical assessment of the possible risks associated with the implementation of planned projects and passing the research results to the staff;

- materiality and expediency, as a principle, are realized by deciding on the necessity and mobility of a feedback to potential threats identified in financial riskprocessing, taking into account the possible costs and benefits of the implementation of response measures to hazards identified;

- prevention, identification and conflict management of internal and external interests implies avoiding collision of different levels interests while implementing the financial risk processing;

- the principle to provide "three lines of protection" developed and applied directly by the Bank of Russia $[10$, p.6] presupposes three-level risk-processing: at the level of risk owners; in the context of divisions that fulfil methodological, controlling and monitoring functions during risk processing; at the participants performing an independent evaluation of the riskprocessing system.

- basing on the possible complete information, $a$ transparent uncertainty demonstration allows to assess objectively the risk degree, taking into account the likely limitations associated with the use of the analytical data obtained in a particular situation;

- continuity implies permanent risk-processing with the subsequent communicating the information about possible threats to the corresponding staff;

- training and motivation are widely used to encourage employees to risk-processing, which enables to enhance the strategic planning efficiency and the activities of the bank as a whole.

This brief overview of the risk-processing principles clearly demonstrates its close correlation with the bank strategic planning, from which the formation and improvement of relevant policies originates. However, we note that implementing every principle is aimed at increasing the efficiency of the regional bank as a whole. Though only an integrated approach is to be applied, since the principles are written down for certain business processes and types of interests: financial-economic, client, market, employees and staff motivation and stimulation; informational and methodological. It worth integrating these directions into the financial risk-process. It will ensure its positive impact on the design and implementation of the bank strategic policy, as far as it will help to actualize and compare the danger of threats, the probable losses resulting from them and the use of feedback tools to prevent them and possible benefits from implementing the appropriate measures.

C. Working out an algorithm and a consistent plan of measures and actions to optimize the reserve accumulation process basing on the model "from AS IS to TO BE»

To implement successful strategic development, the banks should introduce financial risk-processing, which may prove to be quite profitable, as it will help to level the causes and consequences of unaccounted risks.

1. High price and extremely negative consequences of errors. The risk-processing flaws are very dangerous for any bank or credit organization, as its results can be not only a significant financial loss, but, in the most negative scenario bankruptcy.

2. High dependence on core competent employees that are high qualified in risk-processing. Each of them has a range of unique skills and abilities gained from invaluable experience in the sphere of their competencies. The firing or withdrawing such an employee entails a significant efficiency decreasing of risk management and increasing costs to restore the knowledge base lost. Therefore, there is a need to digitalize the financial risk-processing.

Thus, to introduce financial risk-processing is objectively proved. The most adaptive model is "from AS IS to TO BE". The algorithm to introduce the risk-processing into bank management is shown in Fig. 1.

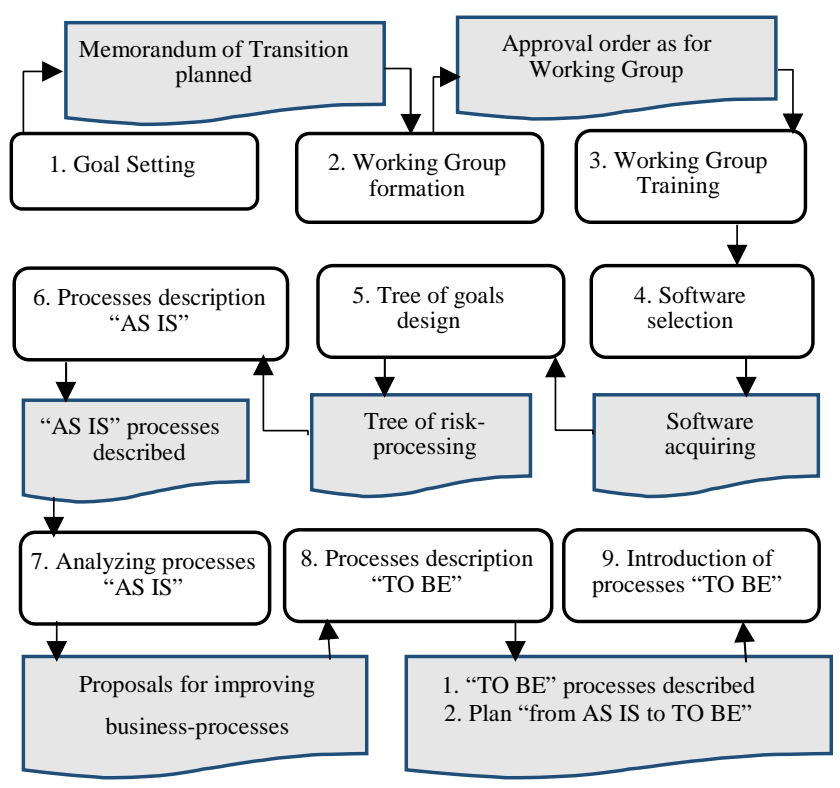

Fig. 1. Financial risk-processing algorithm based on the model "from AS IS to TO BE". 
Analysing the algorithm and scheme of the ASIS process makes it possible to identify two possible areas of optimization. The first of these is due to the multiple process inputs. Each of the bank unit involved (credit department, loans subdivision, middle-office, etc.) sends an e-mail to the employee participating in the implementation of a risk processing specific stage, supervising a certain client. At the same time, if there is no employee in the workplace for a good reason (sick, vacation or business trip), one's mail remains unsorted for a long time. Simultaneously, there is a high risk of delaying the messages and information monitoring or the loss probability when sending materials to the wrong address.

Such a way to provide materials will allow them to be automatically processed and accurately sent to the employee responsible for this stage of risk-processing or supervising this client. This will utterly speed up the workflow and it will streamline the load distribution among the risk department staff, without notifying all the units involved. Those customers, for whom the corresponding employee was not selected by mistake in the subject line of the letter, would be manually processed.

The second potentially problematic area is the process exit. In the ASIS process, a professional judgments or opinions on the client arise from the papers signed and sent to the backoffice. Usually in large credit organizations, the back office is centralized and geographically distant from departments and employees carrying out the risk-processing. It stipulates the necessary to scan the relevant conclusions and documents and send them electronically.

As a result, the risk of inferior processing the documents, and even its loss, that will lead to incorrect reflection of reserves on balance sheet accounts and sanctions introduced to the financial organization by the Central Bank of the Russian Federation.

To optimize this part of the process, it is recommended to computerize the summing up conclusions and professional judgments, by providing the existing banking information system with the preliminary input of the classification parameters to encounter borrowers and clients. This will make possible to eliminate unnecessary operations in the workflow and it will significantly reduce the risk of inaccuracies. At the same time, the following action plan can be formed to implement the transition to the TOBE process (Table II).

Nevertheless, this project can take up to several years from a credit institution or a bank. Bank24.ru has recently spent 9 months for a coherent organizational and technical work, including core processes identification and its description. However, according to the representatives of the bank's management, it took much longer to change the employees mentality including those of strategic positions, and after three years the process was not finalized.
TABLE II. SEQUENCE PLAN OF ACTIVITIES AND OPERATIONS TO OPTIMIZE THE STOCKING UP THE RESERVE ${ }^{\text {a }}$

\begin{tabular}{|c|c|c|c|}
\hline $\mathrm{N}$ & Activity & Deadline & Executor \\
\hline \multicolumn{4}{|c|}{ 1. Optimizing the input to the process (based on "AS IS") } \\
\hline 1.1 & $\begin{array}{l}\text { Creating a single e-mail box for the } \\
\text { risk department }\end{array}$ & \begin{tabular}{c|}
$1-5$ \\
working \\
days
\end{tabular} & IT department \\
\hline 1.2 & $\begin{array}{l}\text { Summing up and forwarding to the IT } \\
\text { department the client list with } \\
\text { instructions of employees who } \\
\text { supervise them }\end{array}$ & $\begin{array}{l}1-5 \\
\text { working } \\
\text { days }\end{array}$ & Risk department \\
\hline 1.3 & $\begin{array}{l}\text { Forming the instruction on the } \\
\text { standard format applying to the } \\
\text { transferring materials }\end{array}$ & $\begin{array}{c}5-10 \\
\text { working } \\
\text { days }\end{array}$ & Risk department \\
\hline 1.4 & $\begin{array}{l}\text { Testing the information system and } \\
\text { software for automatic distribution } \\
\text { and sending the materials }\end{array}$ & $\begin{array}{c}15 \\
\text { working } \\
\text { days }\end{array}$ & IT department \\
\hline 1.5 & $\begin{array}{l}\text { Distribution (intra-bank and client) of } \\
\text { notifications on the transfer to a new } \\
\text { format of the materials sent }\end{array}$ & \begin{tabular}{c|}
$1-5$ \\
working \\
days
\end{tabular} & Risk department \\
\hline \multicolumn{4}{|c|}{$\begin{array}{c}\text { 2. Optimization of the output from the process } \\
\text { (the "TO BE" plan implementation) }\end{array}$} \\
\hline 2.1 & $\begin{array}{l}\text { Development of a technical task for } \\
\text { the digitization of the processing } \\
\text { expert opinions on the risks } \\
\text { identification }\end{array}$ & $\begin{array}{l}\text { up to } 2 \\
\text { months }\end{array}$ & Risk department \\
\hline 2.2 & $\begin{array}{l}\text { Confirmation and final testing of the } \\
\text { bank's software and information } \\
\text { support for risk identification, taking } \\
\text { into account the developed terms }\end{array}$ & $\begin{array}{l}\text { up to and } \\
\text { a half } \\
\text { months }\end{array}$ & IT department \\
\hline 2.3 & $\begin{array}{l}\text { Training the risk department } \\
\text { personnel to work with new software }\end{array}$ & $\begin{array}{l}\text { up to and } \\
\text { a half } \\
\text { months }\end{array}$ & $\begin{array}{l}\text { Risk department, } \\
\text { IT department }\end{array}$ \\
\hline 2.4 & $\begin{array}{l}\text { Training the back-office personnel to } \\
\text { work with new software }\end{array}$ & $\begin{array}{l}\text { up to and } \\
\text { a half } \\
\text { months }\end{array}$ & $\begin{array}{l}\text { Back-office, } \\
\text { IT department }\end{array}$ \\
\hline 2.5 & $\begin{array}{l}\text { The transaction order issue for a new } \\
\text { format of risk processing }\end{array}$ & $\begin{array}{c}1-5 \text { working } \\
\text { days }\end{array}$ & Risk department \\
\hline
\end{tabular}

It seems that the integrated employment of the developed recommendations and proposals will facilitate the financial risk processing implementation and raise the efficiency of the regional bank strategic planning as a whole.

\section{CONCLUSION}

Based on the results of this study, the following conclusions can be summarized.

1. A definition of financial risk-processing is given, under which it is proposed to understand a permanent and prolonged business process to create and form easily applicable common methods for identifying threats and its consequences overcoming.

2. A close correlation between financial risk-processing and forming the regional bank strategic policy has been identified. It is proved that the introduction of risk processing will help to actualize and comprehend the degree of threats, the possible losses caused by them and by the implementing feedback tools to prevent them and potential benefits in case of executing the appropriate measures;

3. The developed algorithm and a consistent plan of measures and actions to optimize the reserve accumulation process based on the model "from AS IS to TO BE" allows to actually assess the existing threats and to find effective means to react.

We emphasize that the practical employing financial riskprocessing by the regional banks will significantly increase the 
efficiency of the strategic planning and operational results of the credit institution as a whole by reducing the costs of identifying threats and choosing the appropriate means to react. This will ultimately have a beneficial effect on the competitiveness of both individual banks and on the sustainability of the regional banking system.

\section{References}

[1] Avdoshin S.M., Pesotskaya E.Yu. "Information technology for financial risk management" [Informatsionnye tekhnologii dlya upravleniya finansovymi riskami.] - "Business Informatics" [Biznes-informatika]. - 2011. N1 (15). pp.42-49

[2] Avagyan, G. L. \& Saitova, M. Yu. "Regional banking cluster.". [Regionalnyy bankovskiy klaster]. Moscow: Magistr Publ.; InfraM Publ., 2012. 224 p.

[3] Altukhova E. V., Zotov V. A., Markov M. A. "Methodical approaches to risk management in a regional commercial bank" [Metodicheskie podkhody $\mathrm{k}$ upravleniyu riskom $\mathrm{v}$ regional'nom kommercheskom banke]. "Economy of the region." [Ekonomika regiona]. 2016. Vol. 12, N. 1. pp. 267-282
[4] Vayn, S. "Resource optimization of a modern bank" [Optimizatsiya resursov sovremennogo banka]. Moscow: Alpina Publ., 2013, 194 p.

[5] Shumilova V.M., Karataev A.S. "Information model of financial risk assessment" [Informatsionnaya model' otsenki finansovykh riskov]. "Modern problems of science and education" [Sovremennye problemy nauki i obrazovaniya], 2012, N 5. pp. 243-252.

[6] Bessis, J. (2011) Risk Management in Banking: Third edition. N.Y.: Wiley Publishing, 840.

[7] Costa, O., Khan, J., Levy, C. \& Natale, A. Risk in Emerging Markets. USA: McKinsey \& Company, 2014, September, p.19.

[8] Meyer, A., Armstrong, J. \& Zelmer, M. An Overview of Risk Management at Canadian Banks. Financial system Review, 2006, pp. 39-47.

[9] Pyle D. H. Bank Risk Management: Theory // Conference of Risk management and regulation in banking (May 17-19, 1997). Jerusalem: UC Berkeley, 1997. - $16 \mathrm{p}$.

[10] "Risk Management Policy of the Bank of Russia" introduced on March 23, 2016 [«Politika upravleniya riskami Banka Rossii» vvedena v deistvie 23 marta 2016.], 2016. [Online resource]: https://www.cbr.ru/today/risk/policy.pdf 